\title{
Arvet från kanslihushögern
}

Recension av Marika Lindgren Åsbrink (red.), Kan(s)lihushögern. Frälsare eller dödgrävare? (Tankesmedjan Tiden, Stockholm 2019)

\section{JAAN KOLK}

Kan(s)lihushögern är utgiven av den socialdemokratiska tankesmedjan Tiden och handlar om den ekonomiska politiken under 1980-talet vilken främst är förknippad med Kjell-Olof Feldt och Erik Åsbrink. Boken är i grunden en försenad vänbok till Erik Åsbrinks 70-årsdag 2017. Baksidestexten vill dock ge den en vidare ram och där det av oklara skäl finns med ett citat från Göran Greider som själv inte medverkar i boken. Det lyder: "Kanslihushögern var en eliternas revolt mot jämlikheten som svensk socialdemokrati än i dag bär djupa ärr efter."

Måhända är syftet med citatet att tona ner karaktären av vänbok samtidigt som det står i bjärt kontrast till bokens huvudbudskap. Ett budskap som väl sammanfattas i rubriken på Allan Larssons bidrag: "Varken höger eller vänster - bara 'crisis mangement'”. Även Anne-Marie Lindgren lyfter fram samma perspektiv i sitt bidrag, där hon menar att det är ett missförstånd att den strid inom arbetarrörelsen där kanslihushögern var en part var av ideologisk art. Den handlade inte om höger eller vänster, utan om verklighetstolkningen: hade verkligheten förändrats eller inte.

Klas Eklund inleder sitt bidrag med ett citat från Nationalteaterns sångtext "Barn av sin tid" från 1978: "Är du rädd för ditt eget barn, lilla mamma". Uppdraget var enligt Eklund att modernisera Sverige. Det uppkom som ett svar på de stora och svåra problem och utmaningar som mötte 1970- och 1980-talets socialdemokrati och stod i samklang med en allmän socialdemokratisk omprövning i omvärlden. 
Merparten av boken utgörs av faktaspäckade texter av socialdemokratiska ekonomer och politiska tjänstemän som ingick i den löst sammanfogade gruppen av "kanslihushögern". Gunnar Lund skriver om den internationella bakgrunden, Michael Sohlman om den stora devalveringen strax efter att Socialdemokraterna återvann regeringsmakten 1982, Lars Heikensten om 1980-talets stabiliseringspolitik, Svante Öberg om skillnader och likheter i den ekonomiska politiken på 1980- respektive I990-talet, medan Jens Henriksson bidrar med ett inlägg om konsten att sätta ekonomisk-politiska mål.

För de mer renodlat politiska texterna svarar Kjell-Olof Feldt och Bengt Westerberg. Feldt kommenterar tre centrala element i den ekonomisk-politiska strategin. Det var den offensiva devalveringen I982, kredit- och valutaavregleringarna 1985-1989 och behovet av strukturella reformer i den offentliga tjänstesektorn. Westerberg tar upp en annan central del av strategin, den genomgripande skattereformen 1990 för vilken Erik Åsbrink var en huvudarkitekt. Den byggde på ambitionen om en enhetlig inkomstskatt där sänkningarna av marginalskatterna skulle balanseras bland annat av höjda kapitalskatter. Folkpartiet var då inne på en 40-procentig skatt på kapitalinkomster, en nivå som i dagens politiska kontext framstår som närmast utopisk.

De i baksidestexten utlovade "kritikerna" av kanslihushögern utgörs av LO-ekonomen Dan Andersson samt Bo Bernhardsson, förbundssekreterare för SSU I98I-I984 och sedermera bland annat riksdagsledamot.

På Dan Anderssons lott föll att skriva om det som kom att kallas för "rosornas krig" där kanslihushögern stod mot LO. Kanske beroende av vänboksperspektivet blir det svårt att få grepp om varför motsättningarna blev så starka. För den som vill få en bättre bild av detta rekommenderas boken Så tänkte vi på LO - och så tänker vi nu. Den kom ut 2012 och är skriven av den tidigare LO-ekonomen Per-Olov Edin, LOordföranden Bertil Jonsson och journalisten Leif Hägg.

I dag blir ingen överraskad av att LO kritiserar regeringens ekonomiska politik och Socialdemokraterna har genom januariavtalet valt att åsidosätta för LO väsentliga intressen. Men vid denna tid var det något nytt att en socialdemokratisk regering helt nonchalerade vad LO tyckte. Så bakom Stig Malms raljanta formuleringar, att han inte "träffat någon 
överhettad byggnadsarbetare" och att den socialdemokratiska riksdagsgruppen "springer som skållade råttor", fanns en frustration över att man inte fick något gehör för de åtgärder som LO-ekonomerna föreslagit för att bringa ner pris- och lönestegringarna och stabilisera ekonomin.

Bo Bernhardsson lägger i sitt bidrag tyngdpunkten på frågan om marknadsreformerna av välfärden. Han avvisar den syn som förts fram både till vänster och till höger om att förnyarna i SSU under 1980-talet skulle vara en del av den marknadsliberala anstormningen, att självförvaltningsidéerna var utväxter på samma förnyelseträd som idéerna som öppnade för privatiseringar. Något som Klas Eklund spinner på i sitt inlägg där han skriver: "Kanslihushögern stod, föga förvånande, på förnyarnas sida."

Självförvaltarnas bundsförvant inom regeringen var snarare civilministern Bo Holmberg, vars uppdrag var att förnya den offentliga sektorn. Han lyfte fram frågan om brukarinflytandet vilket knöt an till en kommunalsocialistisk idétradition inom det socialdemokratiska partiet. Av detta blev det dock inte mycket praktisk politik. I stället kom de borgerliga regeringarna, Bildt 199I-1994 och senare Reinfeldt 2006-20I4, att genomdriva ett systemskifte där nyliberala idéer fick genomslag både genom olika former av privatiseringar och i det som brukar sammanfattas med begreppet new public management. Socialdemokratin drevs på defensiven och kom i huvudsak att acceptera och i varierande grad anamma förändringarna.

Men kanske är ett skifte på väg, i vart fall när det gäller synen på dessa förändringar. Ingvar Carlsson och Anne-Marie Lindgren kom i slutet av 2019 ut med en rejält omarbetad version av boken Vad är socialdemokrati? (också den utgiven av Tankesmedjan Tiden). När den första utgåvan kom I974 låg tonvikten på att skilja ut det socialdemokratiska idéarvet från dåtidens vänstervåg. I takt med att det politiska debattklimatet förändrats har de reviderade versioner som efter hand getts ut kompletterats med en argumentation också högerut. Men det som präglar denna nya utgåva är en kraftfull genomgång och kritik av nyliberalismen och dess effekter på det svenska samhällsbygget. En draksådd som nu skördas av Sverigedemokraterna.

Hur kan man då i dag se på arvet från kanslihushögern? 
ARKIV | NR I2 | RECENSION

"Århundradets skattereform" framstår alltjämt som ett positivt bidrag. Upphovsmännen ska inte lastas för att den övergripande principen om en enhetlig inkomstskatt genom en serie förändringar över tid urholkats. De största skadorna åstadkoms under regeringen Reinfeldt. Behovet av en ny skattereform som tar itu inte minst med frågan om beskattningen av kapital är skriande.

Värderingen av kredit- och valutaavregleringarna är mindre positiv. Inte endast för på vilket sätt de kom att genomföras, vilket starkt bidrog till den ekonomiska överhettningen under 1980-talets senare del och den ekonomiska krisen under regeringen Bildt. Utan också för att de banade väg för den försvagning av nationalstatens möjligheter att kontrollera de finansiella flödena som i dag begränsar det ekonomiskt-politiska manöverutrymmet.

När det gäller de strukturella reformerna inom den offentliga sektorn är det nog mera den socialdemokratiska regeringen under Göran Persson som kom att föra arvet från kanslihushögern vidare.

Det må så vara att kanslihushögern var ett barn av sin tid. Men efterbörden var och är minst sagt problematisk för socialdemokratin. 


\section{REFORMISM OCH UTOPISM}

Wigforss, efterkrigstid och socialdemokratins framtid

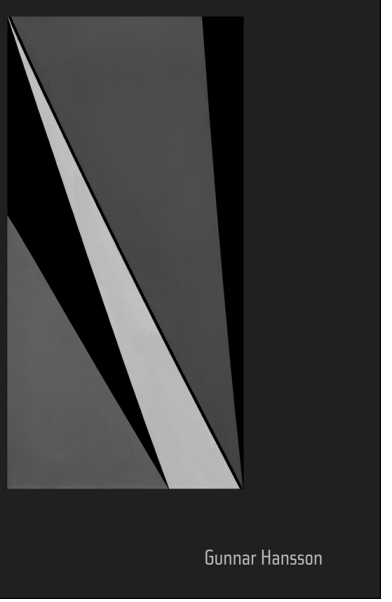

\section{OM SAMHÄLLETS OMVANDLING}

\section{Wigforss och pragmatismens politiska filosofi}

Gunnar Hansson

288 sidor

I Om sambällets omvandling tar Gunnar Hansson upp en förbisedd tanketradition inom svensk socialdemokrati och visar hur stort inflytande den filosofiska pragmatismen hade på Ernst Wigforss politiska idéutveckling.

\section{REFORMISM OCH UTOPISM}

Wigforss, efterkrigstid och socialdemokratins framtid

Gunnar Hansson

I90 sidor

Statsvetaren Gunnar Hansson har i flera böcker behandlat den svenska socialdemokratins ledande teoretiker Ernst Wigforss tänkande. Reformism och utopism handlar om Wigforss försök att utforma en vision för politiskt tänkande och handlande i syfte att skapa ett annat och bättre samhälle.

\section{OM SAMHÄLLETS OMVANDLING}

Wigforss och pragmatismens politiska filosofi

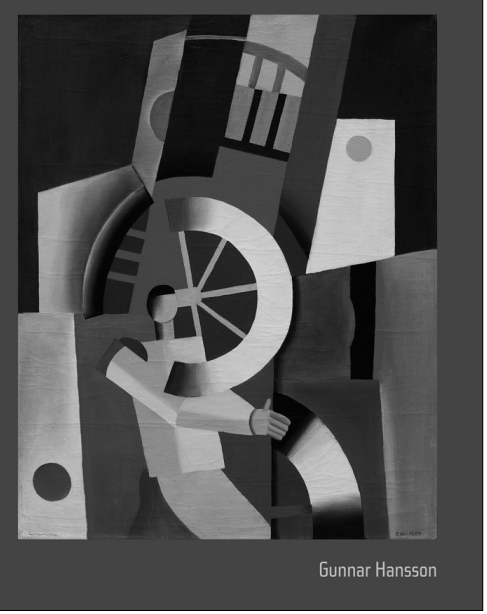

»Böckerna går att beställa i bokhandeln och från www.arkiv.nu« 


\section{Gunnar Olofsson}

\section{Klass, rörelse, socialdemokrati}

\section{Essäer om arbetarrörelsens sociologi}

Arbetarrörelsen är utan tvekan den klassiska "sociala rörelsen". Men hur kan vi bäst förstå framväxten, strukturen och förändringen av en arbetarrörelse och dess ideologi? Vilka begrepp och teorier är mest fruktbara?

Dessa frågor diskuterar Gunnar Olofsson i en rad skarpsinniga essäer om den svenska arbetarklassens formering, den svenska socialdemokratins historia och den svenska modellens bakgrund och innehåll. Förhållandet mellan arbetarrörelse och intellektuella ägnas särskild uppmärksamhet.

Analysen av de "nya sociala rörelserna", främst kvinnorörelsen och miljörörelsen, intar en central plats i denna bok. Det "nya" och det "sociala" i dessa rörelser består i att de är nära kopplade till nya problem, kriser och konflikter inom den rådande samhällsordningen. Nytt är också hur medlemmarnas föreställningar och identiteter formas. Ett centralt tema är vidare hur både gamla och nya sociala rörelser präglas av sitt förhållande till staten.

Arkiv förlag 1995, mjukband, 288 sidor 